\title{
Catchment Management and Its Effects on Arable Lands of Zimbabwe: A Look beyond the Fast Track Land Reform Program
}

\author{
Kosamu Nyoni \\ Faculty of Agriculture and Natural Sciences, Great Zimbabwe University, Masvingo, Zimbabwe. \\ Email: elijahnyoni@yahoo.com
}

Received July $18^{\text {th }}, 2013$; revised August $22^{\text {nd }}, 2013$; accepted September $24^{\text {th }}, 2013$

Copyright (C) 2013 Kosamu Nyoni. This is an open access article distributed under the Creative Commons Attribution License, which permits unrestricted use, distribution, and reproduction in any medium, provided the original work is properly cited.

\begin{abstract}
This study was carried out in selected districts of Mashonaland East and Central provinces of Zimbabwe in 2011 to determine the effects of soil erosion on arable lands and how this related to catchment management. Results show that the highest contribution is $53 \%$ and is obtained from arable land codes 5 and 7 . These fields show signs of excessive sheet and gully erosion. The least contribution is $0.8 \%$ and this is on arable land codes 3,4 and 8 . These fields have properly done conservation works existing. 33\% of the assessed arable lands have conservation works in place whilst $67 \%$ are not protected and as such the fields are eroded. Soil erosion results in the washing away of the precious top soil, responsible for plant growth and infiltration of rain or irrigation water. This reduces the usefulness of such affected arable lands as crops grown on it can't thrive due to lack of soil fertility. The paper recommends that government policies focus more on promoting sustainable land use through integrated catchment area management. This will go a long way in achieving sustainable development in Zimbabwe.
\end{abstract}

Keywords: Catchment Area Management; Integrated Catchment Management; Arable Lands; Sustainable Land Use; Sustainability; Terrestrial Carbon Sequestration

\section{Introduction}

The existence of human beings on earth depends completely on the availability of critical resources such as land, water and foodstuffs. These key assets are derived from the natural environment [1]. Without this natural environment, there can be neither society nor economy [2]. The proper and sustainable utilisation and management of this essential resource can go a long way in sustaining life on mother earth. However, improper and unsustainable utilization of land can result in soil erosion which if left unchecked leads to desertification and the siltation of river systems. Soil erosion is mostly manifested as gullies that render large tracts of land virtually unusable, threatening water supply and quality [3]. In order to curb this problem of soil erosion and its resultant effects, proper catchment management must be implemented.

According to Australia's National Committee on Water Engineering [4], Integrated Catchment Management (ICM) improves and integrates the management of land, water and related biological resources for sustainable and balanced use. The principle of ICM is that the process should involve the whole community in developing the strategic approach to integrated resource use [4]. A catchment is the area from which the rainfall drains into the watercourses through surface runoff. In a catchment, much of the surface is land and a smaller portion consists of the river channel. This paper focused on the management of arable lands in the post fast track land reform program of Zimbabwe. Poor farming systems resulting in soil erosion will eventually result in reduced capacity of river systems.

Water erosion by definition is a process in which soil is detached and transported from the land by the action of rainfall, runoff, seepage and/or ice. Sheet, rill, gully, stream bank and tunnel erosion are terms used to describe commonly occurring types of water erosion [5]. Soil erosion is now regarded as the world's most immediate and urgent problem, especially in the developing countries [1]. It is estimated that about $35 \%$ of the earth's surface is threatened by soil erosion [6]. Soil erosion was also found 
to have a direct correlation with population density [7]. Population increase, poverty and overgrazing are often cited as major causes of degradation particularly in subSaharan Africa [3]. Soil erosion studies in Zimbabwe have indicated estimated annual soil loss due to sheet erosion to be as much as 50 tonnes/ha [8]. It was also shown that there is more soil loss per unit area per year $(8.14 \mathrm{t} / \mathrm{ha} /$ year) using the conventional methods of farming as compared to mulch ripping under zero tillage ( $1.83 \mathrm{t} / \mathrm{ha} /$ year) [9]. [10] estimated that 25 per cent of the communal areas were severely eroded compared to 2 per cent in the commercial areas. [7] found that soil erosion was prevalent in all agro ecological zones, but more pronounced in zones III, IV and V. Zones IV and V are characterized by unreliable rainfall and poor soils. Hence, they are termed marginalized areas.

The conclusion by [10] can be justified by the enactment of the Land Apportionment Act (LAA) of 1930. The LAA resulted in an uneven and unfair distribution of arable land resulting in the minority white settlers (a population of less than 50,000) occupying $51 \%$ of arable land whereas the majority African peasants (a population of about $1,081,000$ ) occupying only $22 \%$ [11]. These were situated in newly established native reserves which were marginalised as well as too small to sustain the population thus resulting in over exploitation of the natural resources and consequently soil erosion. Yields significantly went down thus forcing the Africans to seek for employment in towns, mines or commercial farms for subsistence.

The LAA and its effects did a lot to push the African to take up arms against this gross injustice. This in principle is what led the country to the second chimurenga war as well as the Fast Track Land Reform Program (FTLRP) "third chimurenga" of 2000. This paper sought to determine the effects of soil erosion on arable lands in the post FTLRP era and how this related to catchment management. It tried to prove the point that poor catchment area management at farm level can result in soil loss of arable land.

\section{Methodology}

The study was a baseline survey; hence the methodology employed was meant to give a general indication of what is transpiring in the provinces in the post land reform era.

\subsection{Study Area}

The study was conducted in Mashonaland East and Central provinces of Zimbabwe (Figure 1). For Mashonaland East province the districts selected were: Chikomba, Marondera, Goromonzi, Murewa, Mutoko and Seke. Mazowe, Guruve, Muzarabani, Rushinga, Mt Darwin, Shamva

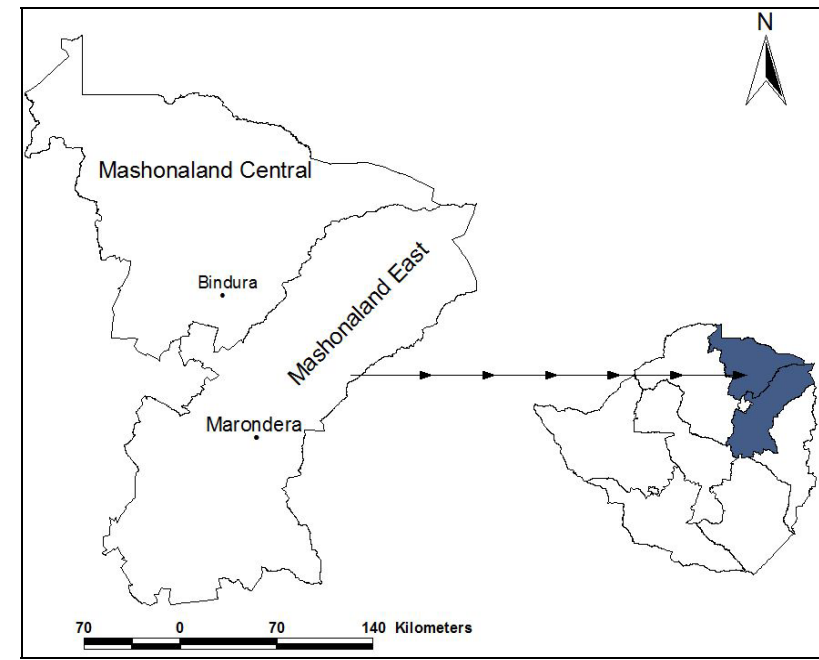

Figure 1. Mashonaland east and central provinces of Zimbabwe.

and Bindura were selected from Mashonaland Central province.

The districts selected range from region II to IV whose rainfall pattern ranges from less than $650 \mathrm{~mm} /$ annum for region IV to between 750 - 1000 for regions IIa and b. [12]. Soils are generally of the kaolinitic order, with patches of the amorphic and natric orders also existing in Mashonaland Central province. The vegetation in the study area is mainly miombo woodlands with small portions of dry savanna [7].

\subsection{Data Collection}

For each province and district visited, the research team included the Chief engineer responsible for Soil and Water conservation issues at national level, his engineer, the provincial head from the department of Mechanisation, his district head and technician responsible for soil and water conservation issues. A rapid and detailed assessment of physical condition of fields was done. Five days were allocated for each province. These assessments were visual and involved observing activities done in arable lands and the land management practices in use. Nine arable lands were visited during this study and of these, seven were of the A2 type, one was A1 and one was large scale commercial. This, however, was rather too small a sample if we would consider the total number of allocated A1 and A2 farms for the two provinces which was estimated at 1295 [13]. This study was thus, a base line survey and it intended to give a general indication of what is transpiring in the allocated lands in the post land reform era. Data collected were analysed in a spreadsheet (microsoft excel). Secondary data was obtained from electronic journals and reports. 


\subsection{Factors that Influence Soil Erosion and Their Weighting}

Absence of infield conservation works to help de-concentrate flood water normally results in soil loss. The following are factors that this study has concluded to be greatly responsible for influencing soil erosion. These are presence or absence of conservation works done according to set standards derived from [14] and tillage system in use. Conservation works were classified according to whether or not they existed. Conformity to standards of conservation works was classified according to whether or not there was adherence to set standards as specified by [14]. Tillage systems were also classified according to whether it was conventional or no till. Table 1 shows the contribution of each tillage system.

For standard conservation works, classification of present was allocated a weight of $5 \%$ as it is assumed to be very minimal. Classification of absent was allocated a weight of $95 \%$ as it is assumed to be very high. No till and conventional were allocated $20 \%$ and $80 \%$ weights respectively. Type of erosion was also classified and weighted as sheet (20\%), Rill (30\%), Gully (50\%).

\section{Results and Discussion}

Thirty three percent (33\%) of the assessed arable lands had conservation works in place (See Figure 2). Sixty seven percent (67\%) of the assessed arable lands were found either without conservation works at all or with conservation works not constructed according to set standards. These arable lands showed advanced sheet and gully erosion in action as shown in Figures $\mathbf{3}$ and $\mathbf{4}$.

Table 1. Classification of standard conservation works, tillage system and weighting for arable lands.

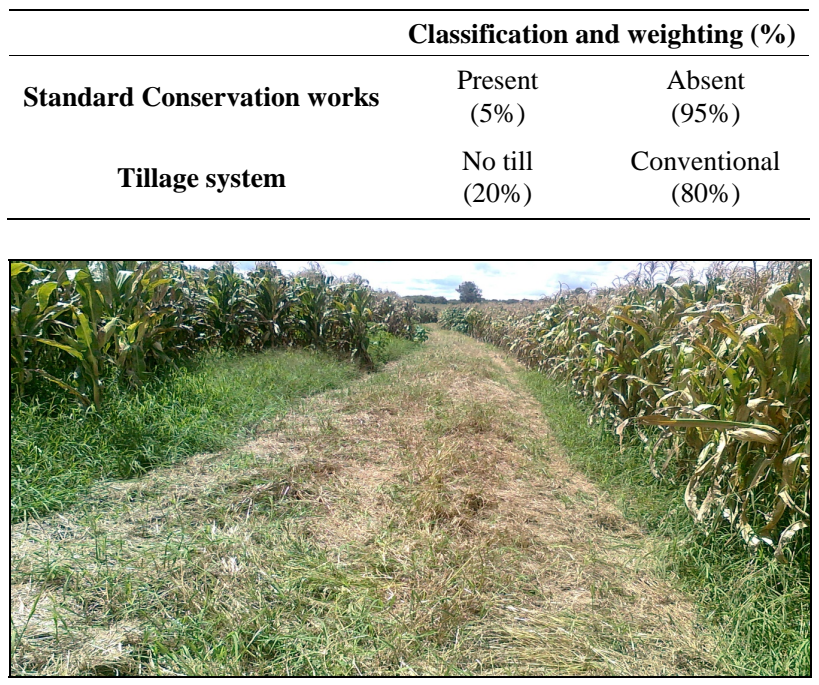

Figure 2. Grassed contour ridge in a protected field in a newly resettled $A 2$ farm (Gambira farm).

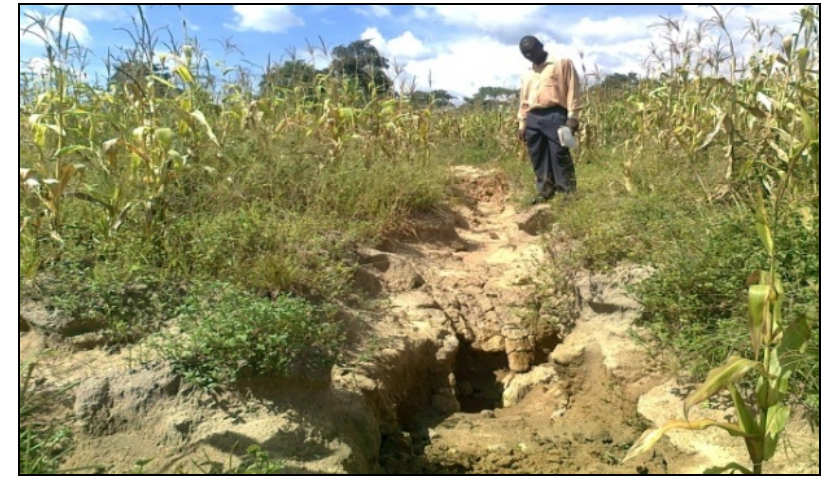

Figure 3. Gully erosion working in an unprotected field in a newly resettled A2 farm in Mutoko District.

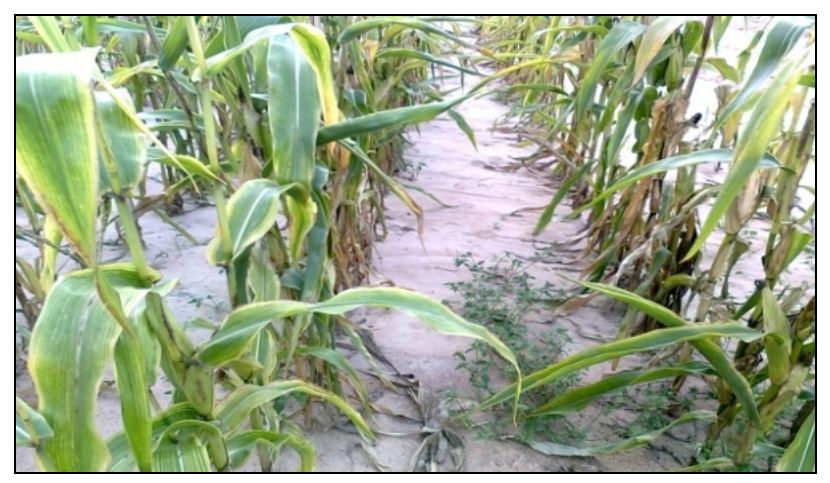

Figure 4. Unprotected field showing activity of sheet erosion in a newly resettled A2 farm in Mutoko District.

Figures 3 and $\mathbf{4}$ were taken from the same field in an A2 farm in Mutoko district. This field did not have conservation works, yet the field's gradient was not gentle. As a result, gully and sheet erosion occurred in the field. Table 2 shows detailed analysis of arable lands and the weighted percentage contributions to soil erosion. The highest contribution was $53 \%$ and was obtained from arable land codes 5 and 7. These fields showed signs of excessive sheet and gully erosion. The least contribution was $0.8 \%$ and this was on arable land codes 3,4 and 8 (See Table 2). These fields had conservation works existing and these were properly done. The contour ridges of the fields had properly matured with a turf of runner grass covering them. On tillage, all the fields investigated were tilled using the conventional method which contributes a lot to erosion as was stated earlier in the paper. There was no field where zero tillage was being practiced.

$67 \%$ of arable lands investigated were found either insufficiently protected or completely unprotected with contribution to degradation ranging between $15 \%$ and 53\%. This shows an inverse correlation between catchment area management and soil erosion. This is so; because catchment area management incorporates sustainability 
Table 2. Arable land and type, standard conservation works, tillage systems, form of erosion active and weighted contribution to soil erosion in the nine arable lands.

\begin{tabular}{ccccccc}
\hline $\begin{array}{c}\text { Arable } \\
\text { land code }\end{array}$ & Sector & $\begin{array}{c}\text { Standard } \\
\text { Conservation works }\end{array}$ & Tillage systems & $\begin{array}{c}\text { Form of } \\
\text { erosion active }\end{array}$ & $\begin{array}{c}\text { Weighted contribution to } \\
\text { soil erosion }\end{array}$ & $\begin{array}{c}\text { Weighted } \\
\text { contribution as a \% }\end{array}$ \\
\hline 1 & A1 & Absent (95) & Conventional (80) & Sheet and rill (50) & $95 \times 80 \times 50=0.38$ & 38 \\
2 & A2 & Absent (95) & Conventional (80) & Sheet (20) & $95 \times 80 \times 20=0.15$ & 15 \\
3 & A2 & Present (5) & Conventional (80) & Sheet (20) & $5 \times 80 \times 20=0.008$ & 0.8 \\
4 & A2 & Present (5) & Conventional (80) & Sheet (20) & $5 \times 80 \times 20=0.008$ & 0.8 \\
5 & A2 & Absent (95) & Conventional (80) & Sheet and gully (70) & $95 \times 80 \times 70=0.53$ & 53 \\
6 & A2 & Absent (95) & Conventional (80) & Gully (50) & $95 \times 80 \times 50=0.38$ & 38 \\
7 & A2 & Absent (95) & Conventional (80) & Sheet and gully (70) & $95 \times 80 \times 70=0.53$ & 53 \\
8 & A2 & Present (5) & Conventional (80) & Sheet (20) & $5 \times 80 \times 20=0.008$ & 0.8 \\
9 & LSCF & Absent (95) & Conventional (80) & Sheet (20) & $95 \times 80 \times 20=0.15$ & 15 \\
\hline
\end{tabular}

and this is greatly compromised in either insufficiently protected or completely unprotected fields due to soil erosion. The study also showed that because of lack of conservation works in the fields, gullies had developed (See Figure 3). Active gully erosion was shown to be occurring in arable land codes 5, 6 and 7. Land reclamation would be necessary if these lands are to be used again productively in the future. This proves yet another dimension that sustainable land use is always in concordance with proper catchment management. This was justified by [15] who said that activities of the resettled farmers are the major perpetrators of soil erosion, which constitutes poor land management. Unsustainable land use is synonymous with environmental degradation (a great stride towards desertification), which eventually leads to social and economic decay.

In some parts of Zimbabwe, it is estimated that 100 tons of topsoil per hectare is lost a year due to unsound land use practices [16]. [1] also pointed out that if care on land management is not undertaken with a sense of urgency, Zimbabwe will be the next Ethiopia. The massive land acquisition that occurred in Zimbabwe meant that there was a substantial movement of people from communal areas into the former white commercial farms [1]. This was done without proper land use planning, a very important component of catchment management. Therefore, proper land use planning was sacrificed from an environmental point of view [1].

There was a possibility of lack of knowledge of sustainable agricultural practices among the resettled farmers. However, this study lacks on this evaluation to prove whether this assertion is true or false, though results seem to point that way. There is need for resettled farmers to be taught of the importance of conserving their environment so that the future generations would also benefit. This, however, has financial implications. It's worth noting that the Zimbabwean economy has been on a downward spiral for about two decades. This down turn of the Zimbabwean economy had a crippling effect on activities of departments responsible for the environment. This is true judging from results in Table 2.

It is also worth noting that some of the eroded material from the affected arable lands eventually finds itself in river systems thus contributing to siltation. The degree of siltation varies considerably depending on the condition of the catchment area [1]. The condition of a catchment area depends fully on its management. Thus, a poorly managed catchment also means a catchment in bad condition. A study in Cajamarca, a province in Peru showed that the encroachment by cattle owners on marginal land caused serious environmental degradation to the region's watershed due to deforestation [17].

Earlier on, it was stated that the total number of allocated A1 and A2 farms for the two provinces was estimated at 1295 [13]. The newly resettled farmers opened up new fields and this resulted in change in land use. Though the issue of land use change was not investigated in this paper, it is worth mentioning and was also mentioned in $[1,15]$ with regards to the land reform program. Land use change affects especially the terrestrial carbon sequestration process. Arable lands are less effective carbon sinks as compared to the woodlands destroyed in opening up fields. This results in more carbon dioxide existing in the atmosphere thus promoting climate change. Climate change results either in increased flooding or increased droughts. This affects catchment management. Flooding results in increased erosion and river siltation. Droughts cause increased water scarcity and negatively affect biodiversity. Climate change impacts negatively on both natural and human systems.

Judging from the results in Table 2, one is tempted to think that Zimbabwe does not have existing and abiding laws concerning the environment. However, [15] proves to the contrary. The environmental laws have been in existence in Zimbabwe since 2002.The implementer and enforcer of these environmental laws is the Environ- 
mental Management Agency [18]. Some of the responsibilities shouldered by EMA are to provide for the sustainable management of natural resources and protection of the environment; the prevention of pollution and environmental degradation; the preparation of a National Environmental Plan and other plans for the management and protection of the environment [18]. However, signing agreements and enacting legislations is not enough when it comes to environmental management [15]. Implementation of these laws is equally important. The question to be paused at this juncture is why soil erosion is increasing by the day when the nation of Zimbabwe has such a vibrant law in place? Table 2 has shown that land management principles are not in use. As a result, sustainability of the precious land resource is being compromised.

Another very important question is: Who is supposed to be in charge of soil and water conservation issues in the catchments of Zimbabwe? Soil and water conservation is a broad subject that requires a coordinated and integrated approach. However, sometimes duplication of efforts is realized. Currently, there has been confusion between the AGRITEX personnel and Mechanization department personnel as to who is supposed to be in charge of soil and water conservation issues in the arable lands. For there to be an effective Soil and Water conservation, a collaborative approach is required by all relevant stakeholders and this must include EMA as well as land holders. In Colombia it was noted that their legislation and competence for the use, management and protection of natural resources are scattered in different sectors which frequently result in conflicts between state officials, duplication of efforts, gaps in the development of activities and ultimately failure by the state to deliver services to its people [17].

\section{Conclusions}

The study has shown that poor catchment management at farm level actually results in loss of arable land through erosion. This is shown clearly from Table 2, Figures 3 and $\mathbf{4}$ where all arable lands without standard contours in place had high weighted percentage contributions to soil erosion ranged from $15 \%$ to $53 \%$. This means that the sustainability of high potential agricultural land is under serious threat as a result of soil erosion. Soil erosion results in the washing away of the precious top soil, responsible for plant growth and infiltration of rain or irrigation water. This reduces the usefulness of such affected arable lands as crops grown on it can't thrive due to lack of soil fertility. It was discussed earlier on in the paper that catchment area management incorporates sustainability and this is greatly compromised in either insuffi- ciently protected or completely unprotected fields due to soil erosion.

The paper also noted that land redistribution results in land use change as woodlands are converted into fields through rampant felling of trees. This land use change normally affects especially the terrestrial carbon sequestration process. Arable lands are less effective carbon sinks as compared to woodlands destroyed in the process of opening up fields. This results in more carbon dioxide existing in the atmosphere thus promoting climate change. Climate change results either in increased flooding or increased droughts. Either of the two impact negatively on both natural and human systems.

Finally, the paper also stated that some of the soil washed away from the arable fields ends up in river systems thus causing siltation. This problem has also been noted in many catchments of Zimbabwe like the Save and the Runde catchments. It can safely be concluded that proper catchment management at arable field level is crucial for sustainable management of the precious soil resource.

\section{Recommendations}

This paper calls for the integrated management of land, water and living resources, a strategy that promotes conservation and sustainable use in an equitable manner. The paper also calls for the empowerment of the EMA so that they will be in a position to do their environmental policing properly. EMA should also work hand in glove with other government departments like the Mechanisation department on soil and water conservation issues both in the old and newly resettled farms. All arable lands must be inspected by the department of mechanisation in conjunction with EMA and if the fields lack the conservation works, they must be pegged and the contour ridges must be constructed. That way, land can be used sustainably. Failure to stick to these requirements by a farmer must be penalised. A negative incentive of some sort must be agreed upon by EMA and the relevant stakeholders. There is also need for land holders to be taught about catchment management and its importance in preserving their lands. Sustainable utilisation of these very important resources must be mastered by all.

All relevant stakeholders should understand the need for an integrated approach to catchment management. They should contribute towards the creation of a proper land use plan that embraces sustainability. There must also be need for integrating economic development and the management of the environment. To achieve this, all hindrances to the integration process must be removed and the process must receive the necessary financial support so that the integration process is fully realised. 
Last but not least, this study was a reconnaissance survey whose time allocation per province was limited to only five days. Financial resources were not permitting for justice to be done on this very important undertaking. The study was rather sketchy and its overall intention was for government to have a refocus on soil and water conservation issues at national level for the benefit of future generations. It is, therefore, the sincere hope of the author that a deeper study is done to further look at the issues highlighted by this paper.

\section{Acknowledgements}

First and foremost, I would like to thank God for His unspeakable gift of life. I also would like to thank the Ministry of Agriculture, Mechanisation and Irrigation Development for their financial support in making this baseline survey a success. I also would like to thank members of staff in the Soil and Water Conservation and Drainage branch for their tireless support during this study. Special thanks also go to Mashonaland East and Central Provinces staff members who actively participated in this exercise. I would like to express my special gratitude to the Inaugural Dean of the Faculty of Agricultural Sciences, Great Zimbabwe University, Professor Munashe Shoko for his support and encouragements. Last but not least, I would like to thank my wife Dorcas and our children, Joshua, Caleb and Jephthah for their continual support.

\section{REFERENCES}

[1] R. S. Maposa, J. Hlongwana and T. Muguti, "Liberation Theology and the Depletion of Natural Resources, a Smart Partnership? An Appraisal on Varimi Vatsva in the Former Commercial White Farms in Zimbabwe,” Journal of Sustainable Development in Africa, Vol. 13, No. 2, 2011, pp. 155-167.

[2] T. Doyle and D. McEachern, "Environment and Politics," Routledge, London, 1998.

[3] A. Booth, J. McCullum, J. Mpinga and M. Mukute, "State of the Environment in Southern Africa," Southern African Research and Documentation Centre (SARDC), Harare, 1998.

[4] National Committee on Water Engineering (NCWE), "Position Paper on Integrated Catchment Management," Australia's Waterfront Newsletter 14, 2010. http://www.ncwe.org.au/pos_papers/icm.html

[5] P. D. Houghton and P. E. V. Charman, "Glossary of Terms
Used in Soil Conservation," Soil Conservation Service of NSW, 1986.

[6] J. D. Unruh, "Nomadic Pastoralism and Irrigated Agriculture in Somalia: Utilization of Existing Land Use Patterns in Designs for Multiple Access of 'High Potential' Areas of Semi Arid Africa,” Geo Journal, Vol. 25, No. 1, 1991, pp. 91-108,

http://landportal.info/sites/default/files/somalia_nomads_ and_irrig_ag.pdf

[7] J. R. Whitlow, "Vegetation in Zimbabwe,” East and SouthEastern Zimbabwe. Papers from the 1987 Study Tour of the Geographical Association of Zimbabwe, 1987, pp. 11-15.

[8] H. A. Elwell, "Modelling Sheet Erosion and Runoff from a Fersiallitic Clay by Combined Small-Scale Physical Simulation Techniques and Field Studies,” Unpublished PhD Thesis, Department of Soil Science and Agricultural Engineering, Faculty of Agriculture, University of Zimbabwe, 1987.

[9] R. D. Smith, "Tillage Trials in Zimbabwe: 1957 to 1988: Report Commissioned for IAE/GTZ-Project 'Conservation Tillage for Sustainable Crop Production Systems',' Hatcliffe, Institute of Agricultural Engineering (IAE), Harare, 1988.

[10] R. Whitlow and B. Campbell, "Factors Influencing Erosion in Zimbabwe," A Statistical Analysis Journal of Environmental Management, Vol. 29, No. 1, 1989, pp. 1729.

[11] V. H. Moyana, "The Political Economy of Land in Zimbabwe,” Mambo Press, Gweru, 2002.

[12] V. Vincent and R. G. Thomas, "An Agricultural Survey of Southern Rhodesia Part 1: Agro-Ecological Survey," Government Printers, Salisbury, 1960.

[13] C. Utete, "Report of the Presidential Land Committee," Government Printers, Harare, 2003.

[14] H. A. Elwell, “Contour Layout Design,” Department of Conservation and Extension, Government Printers, Harare, 1981.

[15] G. Chitiga and P. Chigora, “An Analysis of the Implications of the Fast Track Land Reform Program on Climate Change and Disaster Management in Zimbabwe: A Case of Chegutu District,” Journal of Sustainable Development in Africa, Vol. 12, No. 2, 2010, pp. 124-143.

[16] L. Manjengwa and K. G. Stiles, "Biogeography Module Ged202,” Zimbabwe Open University, Harare, 2000.

[17] UN-HABITAT, “A Guide-Book for Local Catchment Management in Cities,” 2005.

[18] Environmental Management Agency (EMA), "Information and Publicity,” 2011. http://www.ema.co.zw/ 